came generally known. Now these remarks are in no sense derogatory to the value of this product as an article of food. We quite agree with Dr. Playfair that "butterine" may be, and frequently is, very much better than many qualities of butter; but this fact cannot be held to defend or extenuate the practice of substituting "butterine" for butter without the knowledge and consent of the purchaser. The common-sense of buyers and sellers has practically settled this point. The manufacture of "butterine" has now reached such extraordinary proportions that we are bound to recognise it as a legitimate industry : the substance is now sold openly for what it is and on its merits, and it is perfectly obvious that it supplies a public demand. A recent report by Mr. Bateman to the Board of Trade, on the manufacture of these "butter substitutes" in the United States, throws fresh light on the subject, and the statistics which the report contains are calculated to afford a very precise idea as to the magnitude of the industry. The greater part of the substance is made in the States by the patented method of M. Mége Mouries. The process is as follows :-The beef suet, on arriving at the factory, is thrown into tanks containing tepid water, and after standing a short time it is repeatedly washed in cold water, and disintegrated and separated from fibre by passing through a "meat-hasher" worked by steam, after which it is forced through a fine sieve. It is then melted by surrounding the tanks with water of a temperature of about $120^{\circ} \mathrm{F}$.; great care is taken not to exceed this point, otherwise the fat would begin to decompose and acquire a flavour of tallow. After being well stirred, the adipose membrane subsides to the bottom of the tank, and is separated under the name of "scrap," whilst a clear yellow oil is left above, together with a film of white oily substance. This is removed by skimming, and the yellow oil is drawn off and allowed to solidify. The refined fat, as the substance is now termed, is then taken to the press-room, which is kept at a temperature of about $90^{\circ} \mathrm{F}$., and is packed in cotton cloths and placed in galvanised iron plates in a press ; on being subjected to pressure oil flows away, and cakes of pure white stearine remain: these find their way to the candle-makers. The oil is known as "oleo-margarine": it is packed in barrels for sale or export, or is directly made into "butterine" by adding io per cent. of milk to it, and churning the mixture. The product is roloured with annato and rolled with ice to "set" it; salt $s$ then added, and the "butterine" is ready for packing in kegs. The taste of "butterine" is described as being similar to that of second-class butter, but it is rather more salt; owing to the very sinall quantity of the characteristic fats of natural butter-the so-called "butyrin," "caprin," \&c., which it contains, it lacks the flavour of high-class butter. On the other hand, as these fats are specially liable to become rancid, butterine is free from the disgusting smell and taste of the lowest class butters.

The composition of natural butter and of "butterine" may be stated as follows:-

\begin{tabular}{|c|c|c|c|c|c|c|c|}
\hline \multirow{2}{*}{$\begin{array}{l}\text { Water ... } \\
\text { Solids ... }\end{array}$} & & & & & Butter. & \multicolumn{2}{|c|}{$\begin{array}{l}\text { "Butterine." } \\
\text { II } 203\end{array}$} \\
\hline & $\cdots$ & $\cdots$ & $\cdots$ & $\begin{array}{l}\cdots \\
\cdots\end{array}$ & $88 \cdot 032$ & $\cdots$ & $\begin{array}{l}11203 \\
88797\end{array}$ \\
\hline \multirow{4}{*}{ Insoluble Fats } & \multirow{3}{*}{\multicolumn{3}{|c|}{$\begin{array}{l}\text { Olein } \\
\text { Palmitin } \\
\text { Stearin }\end{array}$}} & & $100^{\circ} 000$ & $\ldots$ & 100.000 \\
\hline & & & & $\cdots$ & $23 \cdot 824$ & $\cdots$ & 24.893 \\
\hline & & & & & & & \\
\hline & \multicolumn{3}{|c|}{$\begin{array}{l}\text { Arachin } \\
\text { Myristin } \\
\text { Butyrin }\end{array}$} & $\cdots$ & 51422 & $\cdots$ & 5029 \\
\hline Soluble Fats & \multicolumn{3}{|c|}{$\begin{array}{l}\text { Caprin } \\
\text { Caproin } \\
\text { Caprylin }\end{array}$} & $\cdots$ & $73^{\circ}$ & $\cdots$ & $1 \cdot 823$ \\
\hline \multirow{4}{*}{ 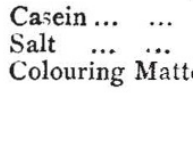 } & $\cdots$ & $\cdots$ & $\cdots$ & $\cdots$ & 92 & $\cdots$ & 0.621 \\
\hline & & $\cdots$ & $\cdots$ & $\cdots$ & & $\ldots$ & $5 \cdot 162$ \\
\hline & & $\cdots$ & $\cdots$ & $\cdots$ & trace & $\cdots$ & trace \\
\hline & & & & & & $\cdots$ & \\
\hline
\end{tabular}

It will be seen that in the main "butterine" is very similar in chemical composition to butter, and its value as an article of food is probably quite as high. Indeed to some people "butterine" might possibly be more wholesome, owing to its comparative freedom from the readily decomposable fats which are apt in some cases to be specially disagreeable; for cooking purposes it may be safely averred that the artificial butter would be generally preferable, owing to the ready alteration of butyrin and its congeners by heat.

The yield of oleo-margarine is found to be about 35 per cent. of the beef caul fat employed, and its present retail price may be set down as about one shilling per pound. It is very difficult to obtain an accurate return of the production of oleo-margarine and butterine ; but it is certain that in the Eastern States of America alone the yearly manufacture is not less than ten million pounds. Chicago and the West, moreover, contribute their share, and Mr. Nimmo, the chief of the U.S. Statistical Department, states that the export of oleo-margarine for the year ending June 30 , I880, was close upon nineteen million pounds. Probably this is under-estimated, for it is almost certain that considerable quantities of "butterine" passed through the Customs under the designation of butter.

The exports of oleo-margarine from the port of New York in 1879 and in the first nine months of 1880 are given in the annexed table:-

\begin{tabular}{|c|c|c|c|c|c|}
\hline Cleared for & & & $\begin{array}{l}\text { Year } 1879 . \\
\text { Pounds. }\end{array}$ & & $\begin{array}{l}\text { January } \mathrm{r} \text { to } \\
\text { Sept. } 30, \times 880- \\
9 \text { months. } \\
\text { Pounds. }\end{array}$ \\
\hline Rotterdam & $\cdots$ & & $\begin{array}{l}\text { Pounds. } \\
\text { 1 1,93 I, I 74 }\end{array}$ & $\ldots$ & $\begin{array}{l}\text { Pounds. } \\
\text { I I, } 127,5774\end{array}$ \\
\hline Antwerp & $\ldots$ & $\ldots$ & I 73,537 & $\ldots$ & $1,367,526$ \\
\hline London... & $\ldots$ & $\ldots$ & 128,426 & $\ldots$ & 58,639 \\
\hline Jiverpool & $\ldots$ & $\ldots$ & $\mathrm{J}, 09 \mathrm{I}, 266$ & $\ldots$ & 590,974 \\
\hline Glasgow & $\ldots$ & $\ldots$ & 274,023 & $\ldots$ & $x, 399,694$ \\
\hline Other ports & $\cdots$ & $\ldots$ & $222,43^{8}$ & ... & I, 215,246 \\
\hline & & & 80,864 & $\cdots$ & $15,759,653$ \\
\hline
\end{tabular}

Of the $15 \frac{3}{4}$ million pounds which were exported in the first nine months of $1880,12 \frac{1}{2}$ millions went to Holland, there to be churned into butterine, most of which is sent into this country. Statistics show that the import of "butterine" into this country from Holland goes on in the same ratio as the import of oleo-margarine from the States into Holland. The poor British farmer has indeed cause to grumble : for not only do the Americans, as he says, send him "acres and acres" of bad weather, and upset all his calculations as to his crops, but the 'cute Yankee and the persevering Dutchman between them give him no chance even with his dairy-produce! The world in general, however, will not complain of "butterine," provided that its composition does not differ materially from that shown by Dr. Mott's analysis given above, but unfortunately from its very nature and the somewhat anomalous position it even yet holds, it is very liable to sophistication, and the people who adulterate butter with oleo-margarine are liable to get the oleo-margarine adulterated to begin with. An ingenious American has recently sought to place butter, as he calls it, on a soapstone basis, by which is implied that finely-ground soapstone added to the fat will, in his opinion, make a marketable commodity! We are told, on high authority, that if we ask for bread we are not to be offered "a stone": neither are we when we ask for butter.

$\mathrm{T}$.

\section{SCIENTIFIC EDUCATION IN LIVERPOOL}

$\mathrm{I}$ the youngest city of the Empire, which on Saturday witnessed the inauguration, by Lord Derby, of its new university, already endowed with more than a hundred thousand pounds, the public recognition of the practical value of scientific education to the community, commenced only in 1860 , when Sir William Brown gave to the town the magnificent pile of buildings forming the Free Library and Museum, which at once received from the late Lord 
Derby his fine natural history collection, and the Museum of Archæology and Art, formed with so much care and cost, by Mr. Meyer, of Bebington.

Previous to Sir William Brown's princely gift little seems to have been done to advance education in Liverpool since 1647, when it was entered in the records, "Ordered that two dictionaries be provyed for the use of this towne and to be chayned." In I86I Sir William Brown stated that the Free Library and Museum would not be complete until it had attached to it a School of Science, which scheme was supported by the then Mayor, Mr. S. R. Graves, and the school was opened in October of that year by Lord Granville, then Lord President of the Council, supported by the Right Hon. W. E. Gladstone and Sir William Fairbairn, president of the British Association for that year. The school was affiliated with the Museum and Library Committee of the Corporation, and at present contains no less than $80 \mathrm{I}$ students, the largest number in any science school in the kingdom. Last year it obtained three scholarships at the Normal School of Science, South Kensington, and four Whitworth scholarships, whilst 8I per cent. of the students passed the Government Science Examinations, winning four Queen's medals and 233 Queen's prizes, and a Government Grant of 694l. In 1865 a period of depression occurred, which ceased in 1868, when Messrs. S. Leigh-Gregson and T. J. Moore, the indefatigable honorary secretaries, made vigorous efforts to improve the attendance, which was most successfully effected by doubling the fees, since when the marked prosperity has been unbroken, and all that is wanted is a central building instead of the present twelve centres of instruction.

A very valuable outcome of this School of Science are the free lectures, given at the expense of the Liverpool Corporation every winter in the Free Library and Museum, on subjects connected with the objects and specimens in the building. The programme for the present session includes numerous lectures on purely scientific subjects; amongst the lecturers are Messrs. Clements Markham, Lant Carpenter, De Rance, Professors R. S. Ball and Campbell Brown.

In addition to the Science School affiliated with the Corporation are the Liverpool Science and Art Classes, established in 1870 , through the energy of Mr. J. Samuelson. There are no less than fifty-one classes held in seven centres; the numbers of students in science are steadily increasing, and by arrangement with the Liverpool School Board their pupil-tearhers are allowed to attend the science classes, so as to qualify them for scienceteachers. In some cases laboratories have been erected at the Board schools, and the School Board have appointed a Science Demonstrator with two assistants of their own. The boys so taught have recently been examined by Prof. Forbes, of the Andersonian University, Glasgow, who reports very favourably of them.

Three years ago it was realised that the existing institutions did not satisfy the requirements of high education in Liverpool, and it was determined to found a University College, in connection with the Victoria University, and in this comparatively short time no less than seven Professors' Chairs have been endowed, with ten thousand pounds each, several chairs being founded by single donors, amongst whom is Lord Derby.

The Council of the College having no large funds to expend in the erection of imposing buildings, have been fortunate to receive from the City Council a large building standing in its own grounds at Brownlow Hill, a site on the brow of the hill 200 feet above the sea, overlooking the public buildings of Liverpool and the broad channel of the Mersey; in the city, yet removed from its traffic and turmoil. The building was originally erected at a cost of $20,000 \mathrm{l}$. ; it contains a rectangular centre with two wings; the solidity with which it was built has enabled Mr. Waterhouse to throw down the compartment walls of the wings, and to convert them into two lecture theatres, holding I 50 students each, while the body of the buildings form council, professors' and class rooms, whilst other rooms bave been fitted up as libraries, natural history, and physical laboratories, and engineering and drawing rooms. There are at present no chemical laboratories, but those of the adjacent medical school being available they are hardly required. The scientific chairs at present filled are those of Physics, Biology and Geology, and Chemistry, held by Professors Lodge, D.Sc., Herdman, D.Sc., F.L.S., and Campbell Brown, F.C.S. respectively. It is to be hoped ere long the wide range of knowledge covered by such sciences as biology, botany, and geology will be separated into at least two chairs, especially as the proximity of the Lancashire and Welsh coalfields render it important that Practical Geology and Mining should find a place amongst the College Chairs.

At the inaugural ceremony on Saturday Lord Derby presided, and showed from the sums that were still coming in that there is likely to be no lack of funds. Among other things he said: "We live in changing times, but democracy appreciates education, and especially appreciates science, and I think the scientific foundation is pretty safe not to be disendowed whatever happens. Let me add only this. Over and above its special educational work our college will do two things. It will be the centre of local patriotism, the means by which local public spirit may freely display itself, and it will give fresh evidence, if evidence is needed, that commerce and culture, so far from being antagonistic, are natural allies. They were so in Athens, they were so in Alexandria, they were so in the Italian Republics of the Middle Ages, and I do not think that a probably busier existence and a certainly smokier atmosphere constitute any reason why they should not be so here likewise."

Prof. Rendall, M.A., in delivering the inaugural address, said :- "The effort inaugurated that day was but one of many, each one wearing, indeed, its distinctive features, but all alike. What meant the simultaneous stir in Birmingham, in Bristol, in Leeds, in Nottingham, in Sheffield? What meant a host of cognate efforts in country towns and in the metropolis, too numerous to recapitulate?. What meant the sudden expansion in want of a college whose fate and trial it was to wait long and work obscurely, sustained rather by belief in its mission than by reassurances of success ? It was easy to say that the forwardness of founders was out of proportion to the zeal of students. As a matter of fact, founders' munificence has met with quick response, and five times out of six it is lack of funds, not lack of classes, that has hindered progress or even entailed defeat; and for predicting a like conclusion there were ample grounds. For primary education in England efficient provision had been made; of secondary and higher education the supply was sparse and capricious; while academic training remained the monopoly of the privileged and the wealthy. Unless the middle classes looked to it they would shortly find their children starting the race of life less well equipped for the inevitable struggle than those who in wealth and social standing have occupied a lower place."

Certainly the Liverpool College has made a most promising start; and considering the wealth of the city, there is no reason why, in a very short time, it should not be in perfect working order.

\section{BJERKNES' HYDRODYNAMIC EXPERIMENTS}

I N NATURE, vol. xxiv. p. 360 , were described in general terms the very interesting experimental researches of Prof. Bjerknes, of Christiania, which excited so much attention at the late Electrical Exhibition at Paris. Our readers will remember that the main point in those re- 